\title{
Influence of protein malnutrition on cutaneous wound healing in rats
}

\author{
Impacto da desnutrição proteica na \\ cicatrização de feridas cutâneas em ratos
}

\section{A B S T R A C T}

\section{Objective}

Investigate histological changes related to inflammatory response and collagen expression during wound healing in rats with protein malnutrition.

\section{Methods}

Twenty male Wistar rats underwent cutaneous surgery and were divided into two experimental groups: Malnourished ( $8 \%$ casein diet); Nourished (17\% casein diet). Animals were euthanized after $5^{\text {th }}$ and $10^{\text {th }}$ days, descriptive and quantitative analyses were performed on sections stained with hematoxylin-eosin and sirius red, respectively. Statistical analysis of data using nonparametric Fisher's exact test with $p<0.05$ was carried out.

\section{Results}

At five days, increased fibroblast proliferation $(p<0.01)$ and collagen expression $(p<0.05)$ was observed in N5 group. After ten days, N10 and MN10 animals showed higher amount of granulation tissue and edema/ inflammatory infiltrate independent of nutritional status $(p>0.05)$, only N10 group showed fibroblast proliferation $(p<0.01)$ and increased collagen expression $(p<0.01)$.

1 Universidade Federal da Bahia, Faculdade de Nutrição, Departamento de Nutrição. Salvador, BA, Brasil.

2 Universidade Federal da Bahia, Programa de Pós-Graduação Processos Interativos dos Órgãos e Sistemas, Departamento de Ciências Básicas. Salvador, BA, Brasil

3 Escola Bahiana de Medicina e Saúde Pública, Faculdade de Odontologia, Departamento de Ciências Básicas. R. Silveira Martins, 3386, Cabula, 41150-100, Salvador, BA, Brasil. Correspondência para/Correspondence to: ARAP MEDRADO. E-mail: <alenamedrado@hotmail.com>

Como citar este artigo/How to cite this article

Sampaio LAS, Costa JS, Freire TFC, Reis SRA, Deiró TCBJ, Medrado ARAP. Influence of protein malnutrition on cutaneous wound healing in rats. Rev Nutr. 2018;30(5):433-42. http://dx.doi.org/10.1590/1678-98652018000500001 


\section{Conclusion}

Protein malnutrition seems not to influence inflammatory phase of healing, whereas it negatively effects fibroblast proliferation and collagen synthesis.

Keywords: Collagen. Malnutrition. Protein malnutrition. Wound healing.

\section{RE S U M O}

\section{Objetivo}

Investigar as alterações histológicas relacionadas à resposta inflamatória e à expressão de colágeno durante a cicatrização em ratos com desnutrição protéica.

\section{Métodos}

Vinte ratos Wistar machos foram submetidos à cirurgia cutânea e divididos em dois grupos experimentais: Desnutridos (dieta com caseína a $8 \%$ ); Nutridos (17\% de dieta com caseína). Animais foram eutanasiados após 5 e 10 dias, análises descritivas e quantitativas foram realizadas em cortes corados com hematoxilina-eosina e sirius vermelho, respectivamente. Análise estatística dos dados utilizando teste exato não paramétrico de Fisher com $p<0,05$ foi realizada.

\section{Resultados}

Aos cinco dias, observou-se aumento da proliferação fibroblástica $(p<0,01)$ e expressão de colágeno $(p<0,05)$ no grupo N5. Após 10 dias, animais N10 e MN10 apresentaram maior quantidade de tecido de granulação e edema/infiltrado inflamatório independente do estado nutricional ( $p>0,05)$, apenas grupo $N 10$ apresentou proliferação fibroblástica $(p<0,01)$ e aumento da expressão de colágeno $(p<0,01)$.

\section{Conclusão}

A desnutrição protéica parece não influenciar na fase inflamatória da cicatrização, porém afeta negativamente a proliferação de fibroblastos e a síntese de colágeno.

Palavras-chave: Colágeno. Desnutrição. Desnutrição proteica. Cicatrização de feridas.

\section{NTROD U C T I O N}

Malnutrition particularly affects thousands of pregnant women, newborns, and pre-school children worldwide [1]. In Brazil, the northern and northeastern regions offer the most precarious living conditions in the country with the highest prevalence of malnutrition [2]. Older children and adults who have survived neonatal malnutrition but who still have insufficient nutrient intake are typically classified as chronically malnourished [3]. Such a nutritional status is the most significant risk factor for increased morbidity and mortality [4]. Experimental studies using animals indicate that wound healing is impaired only after prolonged feed restriction [5].

Protein-Energy Malnutrition (PEM) has an etiology of inadequate food intake and is characterized by energy deficiency due to the low intake of all macronutrients and many micronutrients that can be triggered by the low intake of a specific nutrient, protein [6]. The deficiency of proteins, vitamins, and important cofactors inhibits the synthesis of collagen and retards the repair of wounds [7]. The presence of vitamin $C$ and proteins, in particular, promotes the biosynthesis of collagen, which is a determinant factor in the generation andmaintenance of tensile strength of scar tissue. Thus, a nutritional imbalance induces a series of biochemical and organic changes in humans. In addition, the PEM generates significant morphofunctional alterations, in the skin as well, culminating in loss of integrity and impairment of cicatrization $[6,8]$.

Tissue repair generates an increase in caloric and protein demand, as well as an increased requirement for some micronutrients [3]. In humans, a wound is considered a "threat 
to life" evolutionarily, and consequently healing has priority for the use of available nutrients, especially amino acids acquired at the expense of muscle catabolism [9]. Therefore, greater energy and nutrient consumption are required during tissue repair [10].

Studies have shown the importance of investment in the prevention of malnourishment, recognizing the significance of the relationship between nutrition and healing [6]. To evaluate the various nutritional systems that seek to accelerate or otherwise promote healing, it is necessary to standardize and to understand the experimental models of chronic malnutrition used for the study of mechanisms involved in the tissue repair process, and subsequently to establish the safety and efficacy of products used for nutritional treatment in malnourished patients with healing difficulties. For these reasons, the present study was carried out to analyze the histological changes related to the inflammatory response and the quantification of collagen in the healing of standardized wounds in rats with chronic protein malnutrition.

\section{METHODS}

The present experimental study was carried out at the Experimental Nutrition Laboratory (LABNEX) of the Nutrition School of the Federal University of Bahia. In total, 20 male Wistar rats, aged at least 60 days and up to 70 days, were obtained from the São Rafael Hospital colony and maintained at LABNEX. The study proposal was submitted to the Committee on Ethics in the Use of Animals (CEUA) of the Institute of Health Sciences and approved with protocol number 045/2013.

To generate offspring, male and female Wistar rats aged 90 to 100 days were maintained at LABNEX under controlled temperature conditions $\left(23 \pm 2^{\circ} \mathrm{C}\right)$ and 12 -h light/dark cycles with access to feed and water (ad libitum). Females were placed in the same polypropylene boxes as the male rats, with evaluation of gestation after the third day of mating. gestation was evaluated by observing the increase in body weights of the animals, which were weighed every three days. Pregnancy was confirmed if a weight gain of $30 \%$ of the initial weight was recorded.

The rats were maintained in polypropylene cages and weighed every three days using an electronic scale with a capacity of $4 \mathrm{~kg}$ (Marte ${ }^{\circledR}$, model S-2000C, São Paulo, Brazil).

\section{Diet}

Table 1 shows the composition of the diets used (normoproteic and hypoproteic). Thehypoproteic diet (1 $\mathrm{kg}$ lots) was prepared according to the procedures established by the American Institute of Nutrition (AIN) [11].

\section{Experimental animal groups}

Following a period of 24 hours for litter adjustment, neonates, eight pups per mother, preferably males, were selected for experimentation. The animals were further subdivided into two experimental groups: Nourished $(\mathrm{N})$ and Malnourished (MN). The MN group was composed of 10 rats from nourished mothers (standard diet containing 17\% protein of high biological value), and the $\mathrm{N}$ group comprised 10 rats, also obtained from nourished mothers. The day after birth, the mothers of the animals belonging to the MN group were fed a hypoproteic diet (containing 8\% protein of high biological value) and water ad libitum during the lactation period (from the $1^{\text {st }}$ to the $21^{\text {st }}$ day of life of the pups) [12]. After weaning, the animals continued to receive the same hypoprotein diet and water ad libitum until they were 60-70 days old. The $\mathrm{N}$ group was fed a commercial diet (standard formulation containing $17 \%$ protein of high biological value) and water ad libitum throughout the experiment, from birth until they reached an age of 60-70 days, under the same conditions, of temperature, humidity and lighting. Both diets contained the same amounts of micronutrients. 
Table 1. Composition of Normoproteic and Hypoproteic diets. Salvador (BA), Brazil, 2018.

\begin{tabular}{lrr}
\hline Composition/Type of Diet & Normoproteic & Hypoproteic $^{*}$ \\
\hline Ingredients (g) & & 87.00 \\
Casein & 185.00 & 742.50 \\
Maize starch & 644.50 & 70.00 \\
Soyoils & 70.00 & 50.00 \\
Fibers & 50.00 & 10.00 \\
Vitaminmix & 10.00 & 35.00 \\
Mineral mix & 35.00 & 2.50 \\
Biotin/Coline & 2.50 & 3.00 \\
Methionine & 3.00 & \\
Analysis & & $4.350,00$ \\
Energetic value (Kcal) & $4.350,00$ & 73.00 \\
\%Protein & 17.00 & 15.00 \\
\%Carbohydrates & 64.00 & \\
\%Lipids & 15.00 & \\
\hline
\end{tabular}

Note: "Mixtures of salts and vitamins were formulated according to the recommendations of the American Institute of Nutrition. Purified Diets for Laboratory Rodents Diets, AIN-93, for the stages of growth, pregnancy and lactation and supplied to the experimental animals in the same quantities as the normoprotein diet.

The groups were divided into subgroups according to time (days) until sacrifice after surgery: Nourished, five days (N5, $\mathrm{n}=5$ ); Nourished, 10 days (N10, $n=5) ;$ Malnourished, 5 days (MN5, $n=5)$; Malnourished, 10 days (MN10, $\mathrm{n}=5$ ).

\section{Surgical procedure, sacrifice and histological processing}

The rats of both groups ( $\mathrm{M}$ and $\mathrm{N}$ ) were anesthetized with a mixture of ketamine and xylazine at the rate of $0.2 \mathrm{ml} / 100$ grams in weight. After performing trichotomy of the dorsal region with a razor blade, standardized cutaneous wounds $[13,14]$ were made with a circular $8 \mathrm{~mm}$ diameter scalpel (Biopsy Punch, Stiefel ${ }^{\circledR}$, Köln, Germany).

The edges of the wounds of all the animals were not coapted with any type of suture so that healing would occur by second intention. After the surgical procedure, the rats were kept under individual isolation and inspected daily to analyze bleeding, loss of the crust, and formation of purulent exudate.
At sacrifice, animals were euthanized by an overdose of an anesthetic $(180 \mathrm{mg} / \mathrm{kg}$, IM ketamine followed by $10 \mathrm{mg} / \mathrm{kg}$, IM xylazine). Half of the cutaneous tissue from the wound area (approximately $2 \mathrm{~cm}$ ) was removed and fixed in 10\% buffered formalin solution for at least eighteen hours. Samples of cutaneous tissue were embedded in paraffin and cut into 4-mm-thick sections using a digital microtome. Two sections were stained with Hematoxylin-Eosin (HE) to determine the degree of inflammation of the lesion and Sirius red to visualize the quantification of collagen.

Histological analysis of all sections was performed double blinded i.e., without knowledge of the groups to which the animals belonged, by two calibrated pathologists.

\section{Data analysis}

Analysis of the histological sections was carried out using a Motic ${ }^{\circledR}$ B5 Professional Series microscope (Motic, British Columbia, Canada) equipped with a camera and associated Motic ${ }^{\circledR}$ Image Advance 3.0 computer program. Prior to 
analyzing samples the calibration for each lens was checked by standard image capture from a calibration slide provided by the manufacturer. Specimens were examined by randomly selecting eight areas of approximately $0.1 \mathrm{~mm}^{2}$. Each area was captured at $100 \times$ magnification and saved in Joint Photographics Experts Group (JPEG) format. A semi-quantitative analysis was performed to evaluate the inflammatory process variables such as edema and monomorphonuclear infiltrate, and the intensity of the red color (collagen), adopting the relative scales of absent (0), discrete $(+)$, moderate $(++)$ and intense $(+++)$. To define these histological grades, the following criteria were adopted: when the alteration was present in a percentage equal to or greater than $50 \%$ in the analyzed section, the degree was considered intense; for 25 to $50 \%$ of the tissue, moderate and less than or equal to $25 \%$, discrete [15].

\section{Statistical analysis}

Considering that the primary objective of the study was represented by the number of inflammatory cells and that the smallest difference between the groups would correspond to 15 cells per field in the control (Nourished) compared to 7 cells per field in the group of Malnourished animals with a standard deviation of 5,5 alpha $\%$ and power of the study of $80 \%$, it was estimated that a sample of five animals per group was required. Comparison of the results observed in the different groups on each day of sacrifice was carried out using the free software $\mathrm{R}^{\circledR}$ version 3.2.1 (R Core Team, R Foundation for Statiscal Computing, Vienna, Austria) to apply Fisher's exact nonparametric test at a significance level of $5 \%$.

\section{RES U L T S}

\section{Animals sacrificed on the $5^{\text {th }}$ day}

Tissue sections of the N5 and MN5 groups stained with $\mathrm{HE}$ revealed that granulation tissue was present in the papillary dermis and on the edges of the lesion, which protruded into the central region of the ulcer located below the fibrin crust. Edema was present in both experimental groups and was mainly restricted to the reticular dermis and hypodermis. There were no significant differences between the groups with respect to the presence of edema and inflammatory cells ( $p>0.05$ ); (Figure $1 \mathrm{~A}$ and $B$, Figure $2 A$ and $B$ ).

Increased fibroblast proliferation was observed in the $\mathrm{N} 5$ group compared to that in the MN5 group (Figure 1A and B, Figure $2 C) ;(p<0.01$ ). Fibroblasts appeared as cells with intense nuclear basophilia with cytoplasmic fusiform and rhomboid appearance oroccasionally starlike in shape (Figure $1 A$ and $B$ ).

The dermal collagen matrix, stained with Sirius red, displayed a significant difference between the nourished and malnourished animals. The former group presented moderate staining compared to the discrete quantification of collagen of the Malnourished group $(p<0.05)$ (Figure 1C and D, Figure 2D).

\section{Animals sacrificed on the $10^{\text {th }}$ day}

The tissue sections stained with $\mathrm{HE}$ showed a greater amount of granulation tissue in both study groups and the beginning of the re-epithelialization process. In the MN10 group, there was complete resolution of edema and inflammatory infiltrate (Figure 2A and B), whereas, in some nourished rats, this variable was still present, but these characteristics were independent of the nutritional status of the animals $(p>0.05)$. Fibroblast proliferation was significantly higher in the N10 group $(p<0.01)$. The presence of amorphous, dense regions in the conjunctive matrix of malnourished animals was observed (Figure 3A and B, Figure 2C).

Collagen quantification was the highest in the N10 group compared to that of the MN10 group, in which the staining intensity was 

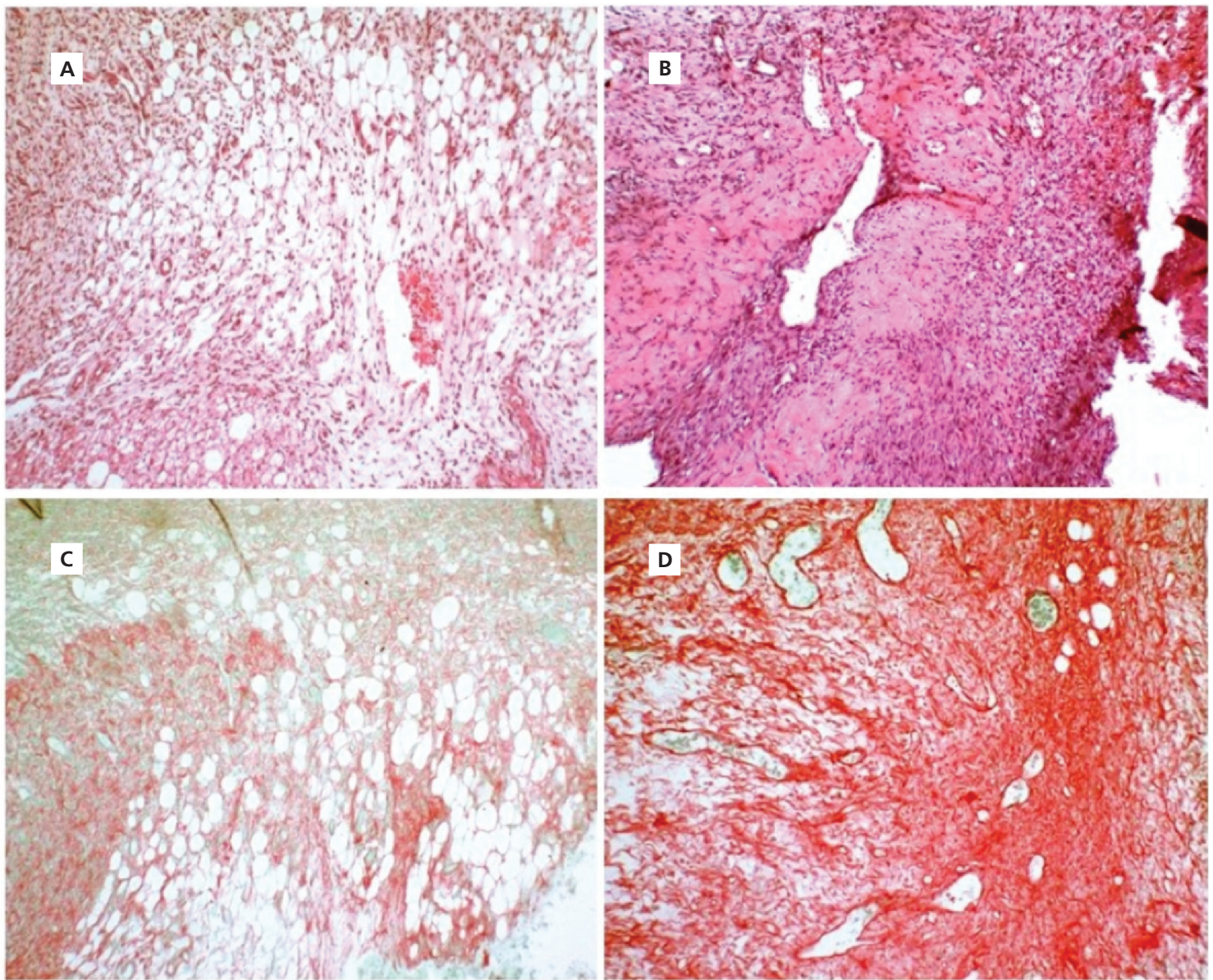

Figure 1. (A) Skin wound area of a malnourished animal killed on the $5^{\text {th }}$ day after skin surgery that shows moderate inflammatory infiltrate and scarcity of edema and (B) skin wound area of a nourished animal that shows intense inflammatory infiltrate and areas of edema. Hematoxylin-eosin, 100x. (C) Fibrocellular stroma showing the presence of sparsely distributed collagen fibers (red) in a malnourished animal sacrificed five days after the standard cutaneous wound and (D) highest color intensity of collagen fibers (red) in a nourished animal. Sirius red, 100x.

Source: Authors (2018)

moderate, presenting a significant difference between the groups $(p<0.01)$ (Figure $3 C$ and $D$, Figure 2D).

\section{DISCUSSION}

The inflammatory response begins immediately after trauma with vasoconstriction due to nerve signaling and the action of mediators from mast cell degranulation, followed by vasodilation [16] and increased vascular permeability, promoting neutrophil chemotaxis to the lesion site leading to edema (inflammatory infiltrate) [17]. As the process of wound healing continues, they contribute to angiogenesis, fibroplasia and extracellular matrix synthesis takes place [16-22].

Proteins ingested or derived from muscle catabolism are metabolized to enzymes, hormones, cytokines, growth factors, and antibody components $[23,24]$. With protein malnutrition, there is a decrease in the expression of cytokines and growth factors involved in both tissue maintenance processes and in wound healing [12,23]. The results of the present study showed a pauci extracellular matrix in 

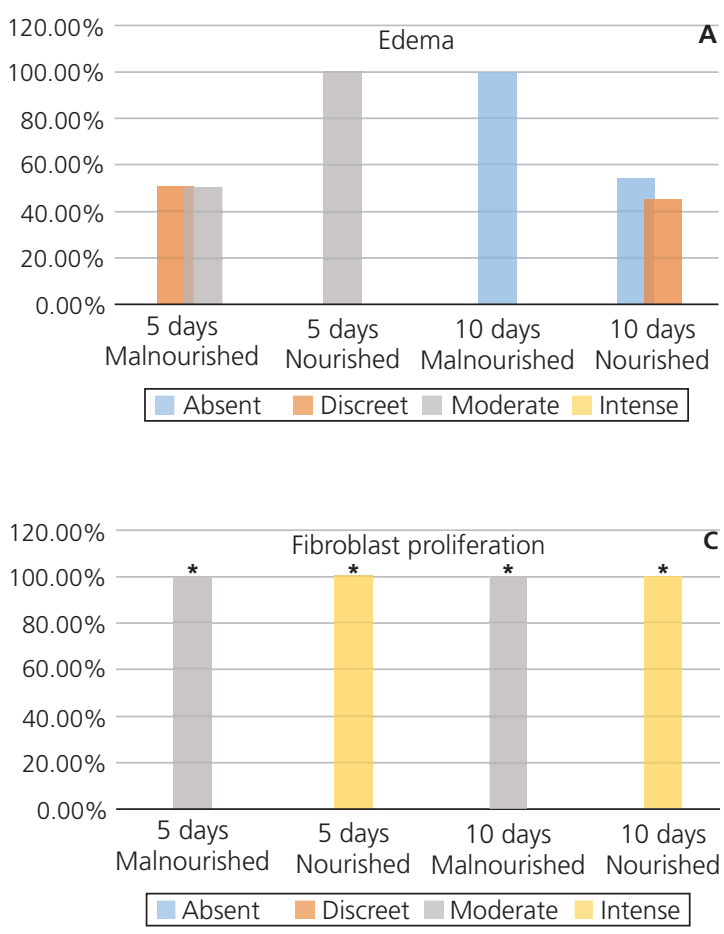
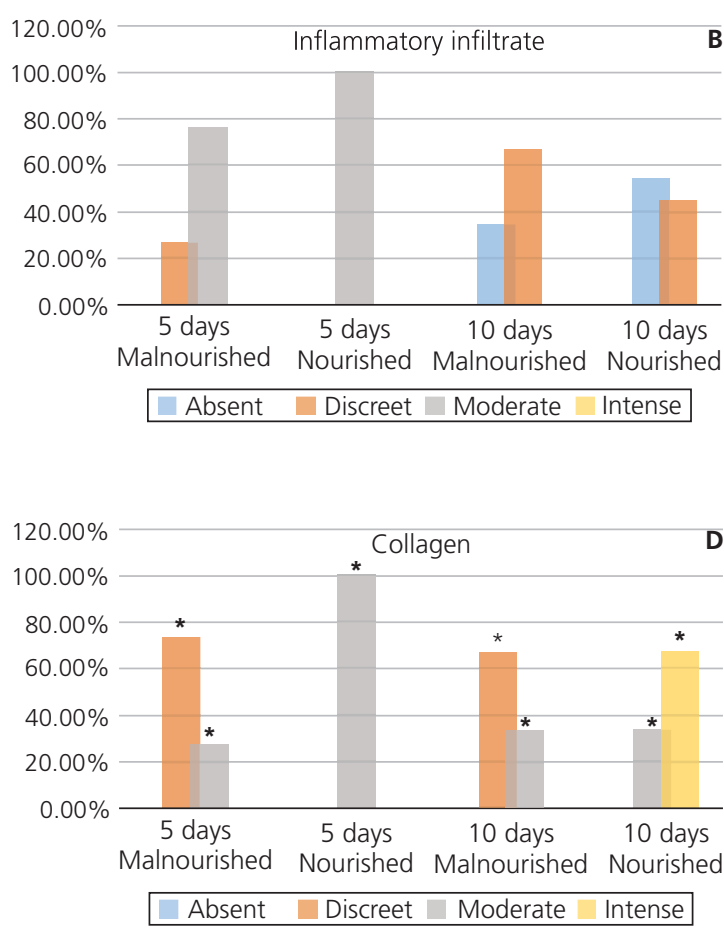

Figure 2. Percentage frequency graph, considering edema (A), inflammatory infiltrate (B), fibroblast proliferation (C) stained with Hematoxylin-eosin and collagen (D) in the tissue sections treated with Red Syriusin groups N5, MN5, N10 and MN10.

Note: *in $C p<0,01$ and *in D $p<0,05$.

both malnourished animals in both periods of the experiment. The complete resolution of the edema and inflammatory infiltrate in tissue sections stained with $\mathrm{HE}$ in the MN10 group suggests a possible compromise in the biosynthesis of cytokines, growth factors, and other chemotactic mediators by macrophages, negatively affecting fibroblast migration and proliferation, and the synthesis of collagen.

Around the fourth day after the lesion establishment, the proliferative phase consisting of the four processes, re-epithelialization, angiogenesis, formation of granulation tissue, and deposition of collagen, $[16,17]$ is generally evident. In the HE-stained sections of rats of both groups, sacrificed on the fifth day after injury, it was possible to verify the presence of typical granulation tissue rich in fibroblasts. These cells presented intense nuclear and cytoplasmic basophilia and exhibited fusiform and rhomboidal morphologies, sometimes star-shaped, indicating high synthesis activity. Although malnourished rats had lower fibroblastic proliferation scores, granulation tissue was present in these specimens. These findings confirm those of Almeida et al. [25], who reported the presence of myofibroblasts in the stroma of malnourished animals. Normally, the proliferative process extends approximately until the $14^{\text {th }}$ day after the wound $[17,22]$.

Protein is necessary for wound healing and its deficiency can result in decreased collagen production, angiogenesis and fibroblast proliferation, delaying the healing of acute and chronic wounds $[7,8,17]$. Tissue repair is a multifaceted process and involves two characteristic steps: proliferation of cells, especially fibroblasts, and synthesis of proteins, especially collagen from fibroblasts. Both stages require proteins as substrates $[9,23,26]$. Thus, it is possible that an organism suffering protein malnutrition may present a lower 

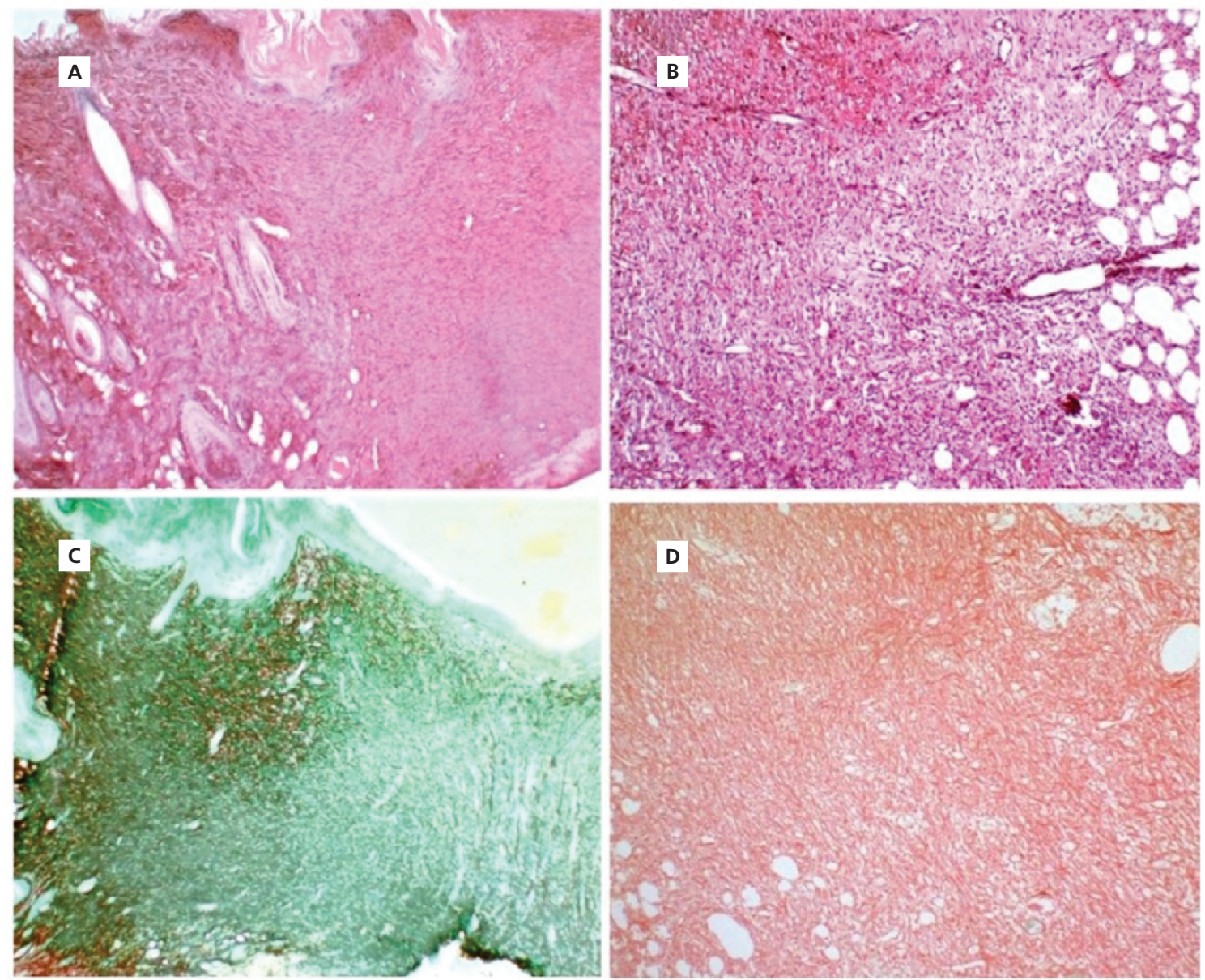

Figure 3. (A) Transitional zone between normal epidermis/dermis and the area of the wound that shows an amorphous stroma and the presence of a discrete infiltrate of inflammatory cells in an undernourished rat, 10 days after surgery and (B) dermis of a nourished animal showing granulation tissue rich in fibroblast cells and blood vessels, 10 days after surgery. Hematoxylineosin, 100x. (C) Area of cutaneous injury of a malnourished animal that illustrates low expression of collagen fibers in the dermis, 10 days after surgery and (D) expression of collagen fibers (red) characterizing the process of fibroplasia in a nourished animal, 10 days after surgery. Sirius red, 100x.

Source: Authors (2018).

degree of fibroblastic proliferation and collagen biosynthesis. This was observed in the HEstained tissue sections of the MN5 specimens compared to the N5 group. The consequence of decreased fibroblast proliferation in animals with insufficient protein intake is a deficiency in the production of collagen [9]. In the present study, in sections stained with sirius red, we observed a moderate quantification of collagen in the N5 group in contrast to the discrete quantification of collagen of the MN5 group. This observation can be interpreted as an apparent consequence of the lower population of fibroblasts in malnourished animals. As there was a significant increase in fibroblast proliferation in the N10 group, the tissue sections of these animals presented collagen of better organizational pattern, with thicker fibers. The histological grade described for this group, in this period, was also higher.

Yamane et al. [27], investigated the effects of changes in wound healing fluid composition and its function caused by protein malnutrition on wound healing. Rats were fed with a $20 \%$ protein diet (control group), or a protein- 
free (group PF) diet for 2 weeks, and then the authors performed full-thickness wounds on the dorsolateral skin. On the $5^{\text {th }}$ day after wounding, frozen sections of wounds were created to investigate the state of granulation tissues, and wound fluid obtained from the rats was collected to examine variations in cytokine levels and its function. The authors observed that wound fluid of rats fed PF diets delays wound healing by inhibiting granulation tissue formation through the suppression of the IGF-1/ ERK (1/2) signaling pathway.

Alves et al. [28] assessed the effect of experimental malnutrition and early enteral feeding with standard diet or diet supplemented with arginine and antioxidants on the levels of mRNA encoding growth factors in acute, open wound healing. Standardized cutaneous dorsal wounds and gastrostomies for enteral feeding were created in Malnourished (M) and Eutrophic Control (E) Lewis male adult rats. The authors concluded that in experimental open acute wound healing, previous malnutrition decreased local mRNA levels of TGF- $\beta 1$ genes, which was minimized by early enteral feeding with standard or supplemented diets.

The results of this study indicate that protein malnutrition has a negative effect on wound healing. The classic model of cutaneous healing adopted in this experimental study has been described in the literature as being reproducible and effective in illustrating processes that occur naturally in humans $[13,14]$. Thus, the observed transformations in the connective tissue matrix suggest that balanced nutrition represents a determining factor for establishing a good healing pattern. Others studies also have similar results and described worse wound healing in malnourished animals $[29,30]$.

\section{CONCLUSION}

In this study, chronic protein malnutrition had a negative influence on the cicatricial pattern. It interfered in the chemotaxis of fibroblasts and their proliferation, and consequently resulted in a lower synthesis of collagen.

The results suggest that some stages of the repair process appear to be unaffected by malnutrition, such as angiogenesis, edema, and inflammatory infiltration. However, malnutrition did lead to the rapid resolution of edema and a lower cellular concentration in the inflammatory infiltrate in the proliferative phase of tissue repair and to a lower quantification of collagen which characterized poor healing in malnourished animals. Further studies should be conducted to broaden understanding of these biological phenomena.

\section{CONTRIBUTORS}

LAS SAMPAIO contributed to the design of the study, analysis and interpretation of data, revision and approval of final version of the manuscript. JS COSTA contributed with analysis and interpretation of data and approval of the final version of manuscript. TFC FREIRE contributed to the interpretation of the data, revision and approval of the final version of the manuscript. SRA REIS contributed to the design of the study, analysis and interpretation of the data and approval of the final version of manuscript. ARAP MEDRADO contributed to the design of the study, analysis and interpretation of data, revision and approval of the final version of the manuscript. TCBJ DEIRÓ contributed to the design of the study, analysis and interpretation of data, revision and approval of the final version of the manuscript.

\section{R E FER E N C E S}

1. Silva $D$, Valente $A$, Borges $A$, Dias $C$, Almeida $F$, Cruz JL, et al. Avaliação entre o estado nutricional materno e o de uma população infantil de São Tomé e Príncipe "África". Rev Bras Saúde Matern Infant. 2017;17(2):337-45.

2. Benício MHDA, Martins APB, Venancio SI, Barros AJD. Estimates of the prevalence of child malnutrition in Brazilian municipalities in 2006. Rev Saúde Pública. 2013;47(3):560-70.

3. Emery PW. Metabolic changes in malnutrition. Eye. 2005;19(10):1029-34.

4. Santos TMP, Silva AKS, Santos CBA, Souza MSG, Lacerdas DC, Santos Júnior JA, et al. Desnutrição: 
uma enfermidade presente no contexto hospitalar. Sci Med. 2015;25(4):1-9. http://dx.doi. org/10.15448/1980-6108.2015.4.21370

5. Hunt ND, Li GD, Zhu M, Miller M, Levette A, Chachich ME, et al. Effect of calorie restriction and refeeding on skin wound healing in the rat. Age. 2012;34(6):1453-8. http://dx.doi.org/10.1007/s11 357-011-9321-6

6. Leite SN, Jordão Júnior AA, Andrade TAM, Masson DS, Frade MAC. Modelos experimentais de desnutrição e sua influência no trofismo cutâneo. An Bras Dermat. 2011;86(4):681-8.

7. Quain AM, Khardori NM. Nutrition in wound care management: A comprehensive overview. Wounds. 2015;27(12):327-35.

8. Serpa LF, Santos VG. Desnutrição como fator de risco para o desenvolvimento de úlceras por pressão. Acta Paul Enferm. 2008;21(2):367-9.

9. Demling $\mathrm{RH}$. Nutrition, anabolism, and the wound healing process: An overview. Eplasty. 2009;9:e9.

10. Arnold M, Barbul A. Nutrition and wound healing. Plast Reconst Surg. 2006;117(Suppl.7):42S-58S.

11. Reeves PG, Nielsen FH, Fahey GC. AIN-93 purified diets for laboratory rodents: Final report of the American Institute of Nutrition Ad Hoc writing Committee on the reformulation of the AIN-76A rodent diet. J Nutrition. 1993;123(10)939-1951.

12. Carvalho-Santos J, Queirós-Santos A, Morais GL, Santana LHS, Brito MG, Araújo RCS, et al. Efeito do tratamento com triptofano sobre parâmetros do comportamento alimentar em ratos adultos submetidos à desnutrição neonatal. Rev Nutr. 2010;23(4)503-11. http://dx.doi.org/10.1590/S14 15-52732010000400001

13. Lima AAM, Spinola L, Baccan GC, Correia K, Oliva $\mathrm{M}$, Vasconcelos $\mathrm{J}$, et al. Evaluation of corticosterone and il-1 $\beta$, il-6, il-10 and tnf- $\alpha$ expression after $670 \mathrm{~nm}$ laser photobiomodulation in rats. Lasers Med Sci. 2014;28(2):709-15.

14. Koo HM, Yong MS, Na SS. The effect of lowintensity laser therapy (LILT) on cutaneous wound healing and pain relief in rats. J Phys Ther Sci. 2015;27(11):3421-3. http://dx.doi.org/10.1589/jpts. 27.3421

15. Soares ES. Efeitos da laserterapia de 660nm na cicatrização de feridas cirúrgicas: estudo histológico e imunocitoquímico [tese]. João Pessoa: Universidade Federal da Paraíba; 2006.

16. Gonzalez ACO, Costa TF, Andrade ZA, Medrado ARA. Cicatrização cutânea: uma revisão da literatura. An Bras Dermatol. 2016;91(5):614-20.

17. Tazima MFGS, Vicente YAMVA, Moriya T. Biologia da ferida e cicatrização. In: Simpósio: Fundamentos em Clínica Cirúrgica; 2008, Ribeirão Preto, Brasil. 2008;41(3):259-64.
18. Campos ACL, Borges-Branco A, Groth AK. Cicatrização de feridas. Arq Bras Cir Dig. 2007;20(1):51-8.

19. Abreu JAC, Sousa AL, Alves CLGF, Nunes JT. Análise histológica da cicatrização de feridas cutâneas experimentais sob ação do laser de baixa potência. Sci Med. 2011;21(3):96-100.

20. Koh TJ, Di Pietro LA. Inflammation and wound healing: The role of the macrophage. Exp Rev Molec Med. 2011;3:e23. http://dx.doi.org/10.101 7/S1462399411001943

21. Isaac C, Ladeira PRS, Rego FMP, Aldunate JCB, Ferreira MC. Processo de cura das feridas: cicatrização fisiológica. Rev Med. 2010;89(3/4):125-31.

22. Mendonça RJ, Coutinho-Netto J. Cellular aspects of wound healing. An Bras Dermatol. 2009;84(3):257-62.

23. Anderson K, Hamm RL. Factors that impair wound healing. J Am Colleg Clin Wound Spec. 2014;4(4):84-91.

24. Raitz R. O papel da matriz extracelular na cicatrização de feridas bucais. Rev Inst Ciênc Saúde. 2008;26(3):351-6.

25. Almeida DS, Souza APC, Meirelles GCS, Santos JN, Pinheiro ALB. Avaliação histológica da desnutrição na cicatrização de feridas em dorso de ratos. Rev Bras Ciênc Saúde. 2003;7(2):49-56.

26. Bottoni A, Bottoni A, Rodrigues RC, Celano RMG. Role of nutrition in healing. Rev Ciênc Saúde. 2011;1(1):1-5.

27. Yamane $T$, Shimura M, Konno $R$, Iwatsuki $K$, Oishi Y. Wound fluid of rats fed protein-free diets delays wound healing through the suppression of the IGF-1/ERK(1/2) signaling pathway. Mol Cell Biochem. 2018;24. http://dx.doi.org/10.1007/s110 10-018-3423-8

28. Alves CC, Torrinhas RS, Giorgi R, Brentani MM, Logullo AF, Waitzberg DL. TGF- $\beta 1$ expression in wound healing is acutely affected by experimental malnutrition and early enteral feeding. Int Wound J. 2014;11(5):533-9. http://dx.doi.org/10.1111/j.17 42-481X.2012.01120.x

29. Wada A, Sonoda C, Makino Y, Hama Y, Nagahama, A, Harada D. Effects of parenteral amino acid administration on the postoperative nutritional status and wound healing of protein-malnourished rats. J Nut Sci Vitamin. 2018;64(1):34-40. http:// dx.doi.org/10.3177/jnsv.64.34

30. Pertille A, Moura KF, Matsumura CY, Ferretti R, Ramos DM, Petrini AC, et al. Evaluation of skeletal muscle regeneration in experimental model after malnutrition. Braz J Bio. 2016;77(1):83-91. http:// dx.doi.org/10.1590/1519-6984.10415

Received: August 22, 2018

Final version: November 5, 2018 Approved: November 13, 2018 